\title{
Turkey and EU/rope: Discourses of Inspiration/Anxiety in Turkey's Foreign Policy
}

\author{
Pinar Bilgin $^{1} \&$ Ali Bilgiç ${ }^{1}$ \\ ${ }^{1}$ Department of International Relations, Bilkent University, Ankara, Turkey \\ Correspondence: Department of International Relations, Bilkent University, Ankara 06800, Turkey. Tel: \\ 90-312-290-2164. E-mail: pbilgin@bilkent.edu.tr
}

Received: November 24, 2011 Accepted: April 26, 2012 Online Published: July 1, 2012

doi:10.5539/res.v4n3p111

URL: http://dx.doi.org/10.5539/res.v4n3p111

\begin{abstract}
The literature on Turkey-European Economic Community/Union (EEC/EU) relations scrutinises how various EEC/EU actors vacillate on Turkey's accession to European integration contingent upon their image/s of Turkey. Turkey's own wavering vis-à-vis EEC/EU, however, is almost always explained with reference to its domestic dynamics (political and economic ups and downs) but not Turkey's policy-makers' image/s of the European Community/Union. What often goes unacknowledged is that throughout the history of Turkey-EEC/EU relations, Turkey's policy-makers' discourses have oscillated between representing EU/rope as a source of inspiration and a source of anxiety. Contra those readings of Turkey's relations with EU/rope as revolving around the dichotomy of 'Turkey being European/not', our analysis of Turkey's policy-makers' discourses on EEC/EU at key moments of the relationship during 1959-2004 shows that Turkey's policy-makers' representations of EU/rope are structured around three binaries that give away a persistent ambivalence vis-à-vis EU/rope as a source of and a solution to Turkey's insecurities. Such ambivalence, in turn, is not uncharacteristic of post-colonial encounters.
\end{abstract}

Keywords: European Union, Turkey, post-colonialism, ambivalence

\section{Introduction}

The literature on Turkey-European Economic Community/Union (EEC/EU) relations scrutinises how various EEC/EU actors vacillate on Turkey's accession to European integration contingent upon their image/s of Turkey (Buzan \& Diez, 1999; Krieger, 2006; Müftüler-Baç \& McLaren, 2003; Rumelili, 2004). Turkey’s own wavering vis-à-vis EEC/EU, however, is almost always explained with reference to its domestic dynamics (political and economic ups and downs) (Öniş, 2003; Rumford, 2002; Uğur, 2004) but not Turkey's policy-makers' image/s of the European Community/Union (Note 1). What often goes unacknowledged is that throughout the history of Turkey-EEC/EU relations, Turkey's policy-makers' discourses have oscillated between representing EU/rope as a source of inspiration and a source of anxiety.

Contra those readings of Turkey's relations with EU/rope as revolving around the dichotomy of 'Turkey being European/not' (see, for example, Çalış, 2001; Dağ1, 2001; Kösebalaban, 2007) - we argue that Turkey’s policy-makers' discourses are structured around three binaries that do not revolve around a single dichotomy as such. These binaries are drawn from our analysis of Turkey's policy-makers' discourses on EEC/EU at key moments of the relationship during 1959-2004. Throughout the years, Turkey's policy-makers have represented EU/rope (Note 2) both as a basis of and an answer to Turkey's diplomatic, economic and political insecurities:

Binary 1: EU/rope as insurance against/source of the risk of diplomatic isolation vis-à-vis the International Society (B1a/B1b)

Binary 2: EU/rope as booster of/ hindrance against Turkey's economic development (B2a/B2b)

Binary 3: EU/rope as a community of values that is accepting/rejective of Turkey (B3a/B3b)

In what follows, we argue that the notion of ambivalence best describes Turkey's policy-makers' stance vis-à-vis Europe; that such ambivalence can be traced back to early Republican leaders' (Note 3) encounters with the International Society; and that notwithstanding post-1999 advances in Turkey-EU relations, Turkey's policy-makers continue to represent the EU/rope as a source of inspiration and anxiety. 


\section{Ambivalence in Turkey's Foreign Policy Discourses: Inspiration/Anxiety}

What is meant by ambivalence is the in-between bearing of Turkey's policy-makers as they speak of EU/rope. In Post-colonial Studies, ambivalence is understood to be a product of not a mere moment of indecisiveness but the very nature of the relationship between the coloniser and the colonised. The latter mimics the former in the attempt to preserve the self but the end-product is - in Homi K. Bhabha's $(1984,1994)$ words - 'almost the same, but not quite'. In turn, the former wants the latter to be similar but not to the extent that $\mathrm{s} /$ he would demand equal treatment. Ambivalence as such characterises the relationship of wanting to be 'similar' and producing 'hybridity'; fearing the absence of 'sameness' and remaining 'different' nevertheless.

L.H.M. Ling's (2002) analysis of West-Asia relations is particularly insightful here. In her book entitled Postcolonial International Relations: Conquest and Desire between Asia and the West, Ling shows how 'Western' - 'Asian' relationship is characterised by 'conquest' and 'desire'. While the developed West conquers the developing Asia, it at the same time desires the latter in that it wants Asia to be dependent. Asia, in turn, 'burns with its own dreams of conquest and desire' (Ling, 2002, p. 17). What Ling is particularly interested in is 'postcolonial learning' that grows through these ambivalent encounters. She writes:

Unfolding postcolonially, learning stems from the interstices of power, where Self and Other collide, overlap, and contradict. Only the powerless encounter these interstices most painfully...Simulation and mimicry of the powerful, then, become the most direct means of survival despite their self-denying, self-humiliating implications. But through postcolonial learning, the powerless eventually learn to reconcile, synthesize, and hybridize across opposing systems, thereby turning an irrational imposition of power into a rational mechanism for survival and, possibly, prosperity (Ling, 2002, p. 18).

Following Ling, we offer a reading of Turkey's policy-makers' bearing toward EU/rope as ambivalence - inspired by the West yet anxious about it all the same.

Perhaps because the Ottoman Empire escaped being colonised (Note 4), insights gleaned from Post-colonial Studies are rarely sought in the study of its international relations. Yet they prove useful in understanding Turkey's policy-makers' stance toward EU/rope as a source of inspiration and a source of anxiety. At the time of its founding, Turkey's Republican leaders were both inspired by and anxious about Europe. The former aspect of their stance is well-articulated in the literature (Heper, Öncü, \& Kramer, 1993). As regards the latter aspect, Turkey's Republican leaders came from a long line of Westernizing reformers who desired to benefit from the fruits of the Enlightenment and sought to emulate the successes of the nation-state model. Yet they also were anxious about Europe in so far as they felt they had a difficult choice between joining the International Society by fulfilling its requirements (Bull \& Watson, 1985; Watson, 1992) or risk losing full sovereignty and/or independence. While the Ottoman Empire had officially been integrated into the International Society since 1856 (Naff, 1984; Yurdusev, 2004), the capitulations remaining in place suggested that the Empire was still not treated as an equal (Note 5). Having observed (if not come to the brink of experiencing) how falling short of meeting the standards of civilisation had proven costly for colonised peoples, Turkey's policy-makers had become anxious of European great powers' ambivalence toward Ottoman status inside/outside International Society.

At the time of its founding in 1923 the Republic of Turkey was in need of recognition as an equal by the European great powers, thereby removing the grounds for intervention and making room for sovereign development (Note 6). This latter aspect of Turkey's policy-makers' stance toward Europe remains relatively untouched by the literature on Turkey's international relations. The kind of insecurities European great powers generated for Turkey were non-military and non-specific (Note 7). Turkey's insecurities were non-military in that the gains of the National Struggle had been sealed through the Treaty of Lausanne (1923). However, while Lausanne had reaffirmed Turkey's hard-won sovereignty, independence and territorial integrity, the Republican leaders were nevertheless concerned about the fragility of such recognition. Turkey's insecurities were non-specific in that they did not stem from the specific act of a specific counterpart. Rather, Turkey's policy-makers represented their actions as responses to what the future may bring, based on their particular remembrances of the past and interpretations of the present. From the perspective of early Republican leaders, Westernization was not only a life-style choice. It was also more than a significant part the Republican project of emancipation. It was a crucial aspect of the strategy of seeking security in the face of a Europe that had, in the past, refused equal treatment to the Ottoman Empire by virtue of its apparent lack in terms of the standards of civilisation. In the early Republican period, Westernisation did not only help Republican leaders achieve their Enlightenment ideas and ideals in Turkey but also helped Turkey to meet the standards of civilisation. This, in turn, allowed Turkey's leaders to claim the right to be treated equally and with respect (Note 8). 
Two caveats are in order here: First, this is not to reduce Turkey's modernisation and/or Westernization to seeking 'similarity' (understood in the everyday sense of the term), but to underscore the parallels in the experiences of various peoples around the world in their encounters with the International Society. Far from the 'benevolent' image projected in the English School literature, the International Society was a source of anxiety for a broad range of non-European actors who faced unequal treatment (if not colonisation) if and when they were found to be lacking in terms of the standards of civilisation (Suzuki, 2005, 2009). Second, the point made here is different from the one frequently made in the literature regarding Turkey's foreign policy legacy, i.e. the first President of the Republic Mustafa Kemal Atatürk's mistrust of European diplomacy. Atatürk is quoted to have said, in the early years of the National Struggle (1919-22), that 'our nation's fault is to have manifested over-confidence in the honesty of Europe' (Note 9). While such mistrust has been explained with reference to Atatürk's foreign policy stance of 'no total confidence in friends or the outer world' (Note 10), the productive tension between seeing EU/rope both as an inspiration and a source of anxiety is better captured by the notion of ambivalence.

In what follows, the article traces the trajectory of Turkey's policy-makers' representations of EU/rope since 1959. Our analysis focuses on key moments of the Turkey-EEC/EU relationship (Note 11). These key moments are: Turkey's application to join the European Economic Community (EEC) in 1959; the Ankara Agreement of 1963 which established a partnership with the perspective of realizing a customs union; the signing of the Additional Protocol in 1970; Turkey's 1978 demand to suspend its obligations originating from the Protocol; Turkey's full membership application in 1987; the signing of the Customs Union Agreement in 1995; the 1997 rejection of Turkey's candidacy and Turkey's decision to suspend political dialogue with the EU; the European Union's recognition of Turkey as a candidate country in 1999; and the $2004 \mathrm{EU}$ decision to begin accession negotiations (Note 12). Altogether they show that Turkey's policy-makers' representations of EU/rope do not revolve around a single dichotomy (Turkey being European/not) but are structured in three binaries. The complex way in which these representations are employed by Turkey's policy-makers give away a persistent ambivalence vis-à-vis EU/rope as a source of and a solution to Turkey's insecurities. Such ambivalence, in turn, is not uncharacteristic of post-colonial encounters.

\section{Turkey Applies to Join the European Economic Community (1959)}

The European Economic Community has its origins in the post-World War II collaboration of Jean Monnet and Robert Schuman who jointly devised a plan for a European common market primarily in coal and steel, two staples of the arms industry, toward preventing a repetition of the experiences of the two devastating wars of the first half of the $20^{\text {th }}$ century. In 1950, they presented the plan to the German Chancellor Konrad Adenauer. The European Coal and Steel Community was founded in 1952, with Belgium, Italy, Luxembourg and the Netherlands joining France and Germany. The cooperation between 'the Six' expanded during the 1950s and paved the way for new areas and arenas of cooperation. 'The Treaties of Rome' founded the European Economic Community (EEC) and the European Atomic Energy Community (Euratom) in March 1957. The EEC set up a common market on the basis of a customs union.

Turkey had emerged from WWII in a frail state. While it had remained outside the hostilities and declared war on Germany and Japan only toward the end of the War (1 March 1945) its economy and society were adversely affected in apprehension of joining the War. Such frailty, when coupled with the Soviet Union's unwelcome post-WWII advances (regarding the status of the Bosphorus and Dardanelles Straits and two Eastern provinces, Kars and Ardahan) facilitated Turkey's decision to seek membership to the North Atlantic Treaty Organization (NATO) and closer relations with the United States (Cos \& Bilgin, 2009). By the time Turkey applied for EEC membership, it had already joined the Council of Europe (1949) and NATO (1952).

Turkey's policy-makers' discourses on the EEC membership application reveal two representations of EU/rope prevailing at the time: a source of the risk of diplomatic isolation vis-à-vis the International Society (B1b) and a booster of economic development (B2a). To start with the former, the decision to apply for EEC membership seems to have been made in haste, following receipt of the news about the Greek application. Within 15 days of hearing of Greece's news, the application was prepared and submitted by the Demokrat Parti (Democratic Party, DP) government. When the decision to submit the membership application was brought to the attention of the Cabinet on 30 July 1959, Prime Minister Adnan Menderes challenged his Ministers by saying: 'Is there anything Greece can do and we can't?' (cited in Birand, 2000, p. 54). While the PM's words revealed a competitive streak with Greece, it also gave away an element of anxiety, which further crystallised in his Foreign Minister's statements on the subject. Semih Günver, then head of Foreign Ministry's Office of International Economic Affairs and a close collaborator of the Foreign Minister Fatin Rüş̧ü Zorlu, related in his memoirs what the Minister told him on that occasion: 
We will at once apply to join the Common Market. We cannot let Greece enter and settle in Europe on its own. This is not only an economic but also political affair. If Athens joins the Common Market and we don't, it will cause us trouble in the future (Günver, 1985, p. 105).

It is significant to highlight here that, at the time, the centrality of Greece to Turkey's policy-makers' discourse appeared to be contingent on Turkey's anxiety vis-à-vis EU/rope (especially if it were to allow Greece in but not Turkey) but not directly associated with bilateral relations with Greece or the conflict over Cyprus.

Even as they represented EU/rope as a source of the risk of diplomatic isolation vis-à-vis the International Society, Turkey's policy-makers also portrayed EU/rope as a booster of Turkey's economic development. One of the most important foreign policy issues for Turkey at the time was easing the foreign exchange deficit. Indeed the $5^{\text {th }}$ Menderes government program (1957-1960) referred to the EEC membership application in the context of the foreign exchange deficit. Similarly, on the occasion of a foreign policy speech delivered at the Grand National Assembly, the Premier framed the EEC as a project designed to establish a free trade area and make financial aid available toward developing the economies of relatively less developed countries of Western Europe (Sükan, 1991). The implication being, by joining the EEC Turkey would also benefit from such aid. Likewise, Foreign Minister Zorlu underscored the centrality of economic concerns to the government's reasoning when speaking to the Press. Zorlu reminded them that concerns regarding the economy were of utmost importance in the decision to apply for membership. He said: 'Turkey is entering to the Common Market in order to strengthen its economy' ("Hariciye ve Savunma Vekilleri Paris'e Gitti," 1959).

To summarize, then, at the time of Turkey's application to join the EEC in 1959, both Menderes and Zorlu publicly represented the issue of membership to EEC as an answer to Turkey's dire economic situation at the time (B2a) while privately voicing their anxiety vis-à-vis the new political formation in Europe (B1b), thereby exhibiting DP's ambivalence toward EU/rope at a time when relations were moving full speed at the European Council (Karaca, 2010, pp. 17-133).

\section{The Ankara Agreement (1963)}

DP was removed from office with the May 27, 1960 coup d'etat. Following 17 months of direct rule by the Military, on 20 November 1961 a government was formed by İsmet İnönü, Head of Cumhuriyet Halk Partisi (Republican People's Party, RPP) and former President of the Republic.

RPP's representation of the EEC constituted a change from that of DP in that while RPP policy-makers de-emphasised the economy dimension, they underscored the political impact of relations. The primary non-military and non-specific insecurity of RPP policy-makers was Turkey being excluded from the International Society. Evidence of persisting anxiety vis-à-vis EU/rope (B1b) could be found in Foreign Minister Feridun Cemal Erkin's address to the Grand National Assembly in 1962. Erkin, who had previously served as Turkey's Ambassador to Washington, DC (1948-1955) and contributed to the effort to secure Turkey's NATO membership, said: 'our main objective is to avoid being left out of the process of European economic integration and ensuing political integration. It is not difficult to understand what remaining outside such a process would mean' (Çayhan, 1997, p. 40). Evidence of RPP government's de-emphasis on the economic dimension could be observed in an article published in the daily Ulus by Turhan Feyzioğlu, Deputy Prime Minister responsible for relations with the EEC:

more important than the short-term gains of the membership to the EEC, Turkey's efforts to become a European state achieved a new victory with this agreement. Turkey's hope to be a member does not result from only short-termist and simple foreign trade calculations. With this agreement, it is proven in the most precise way that Europe's borders end where our southern and eastern borders lie (quoted in Sezer, 1974, p. 522).

On 12 September 1963 the Ankara Agreement was signed between Turkey and the EEC. Providing that Greece and Turkey were not industrialized enough for competing with the economies of the existing members, the EEC offered them both gradual membership to the customs union following which they could apply for fully joining the common market. On the occasion of the signing ceremony in Ankara, Foreign Minister Erkin gave a speech portraying the agreement as 'unique'. He went on to underscore how the Ankara agreement 'reaffirmed' Turkey's desire to become a part of EU/rope and promised 'peace and prosperity' in the future ("Ortak Pazar Antlaşması İmzaland,," 1963). In his address to the Senate, Prime Minister İönü reiterated his Foreign Minister's words: "With this agreement, we think that we have made serious progress in the way towards Turkey's Westernization, which was decided by Atatürk as a national policy' (Karluk, 2003, p. 534). The point being, the Premier and his Foreign Minister represented the Ankara agreement as a next step in the Republican project of Westernization. 
To sum up, elements of DP's ambivalence vis-à-vis EU/rope were also visible in RPP policy-makers' discourses. They clearly viewed EU/rope both as a source of (B1b) and a solution to (B1a) the risk of diplomatic isolation vis-à-vis the International Society. As such RPP of the 1960s exhibited continuity with early Republican leaders' representations of European great powers.

\section{Turkey-EEC Additional Protocol (1970)}

The first 5-year transition period as stipulated by the Ankara Agreement ended in 1968. The negotiations for the second 5-year transition period began in the same year. Turkey-EEC Partnership Council held their first meeting on 5 April 1968. During this period, single party governments formed by Süleyman Demirel, Head of Adalet Partisi (Justice Party, JP), came into office (1965-1969, 1969-1971). Foreign Minister İhsan Sabri Çağlayangil spoke to the Press following a visit to Germany for negotiations with the EEC and represented the 5-year transition period as providing a 'model' toward furthering Turkey's industrialization efforts (Uygun, 1969). In an article published in the official journal of the İstanbul Chamber of Commerce in the same year, the Foreign Minister reminded the readers that 'Turkey, since its early reform period and especially since the foundation of the Republic, has considered itself as a member of Europe and as a member of the free world'. Çağlayangil went on to associate membership to the EEC with this early Republican ideal, thereby exhibiting continuity with previous RPP governments. In the rest of the article, Foreign Minister Çağlayangil emphasised the financial benefits of EEC membership (Çağlayangil, 1969). As such, Çağlayangil brought together two sets of threads in DP and RPP governments' discourses on EU/rope: namely, EU/rope as a booster of Turkey's economic development (B2a) and $\mathrm{EU} /$ rope as insurance against the risk of diplomatic isolation vis-à-vis the International Society (B1a).

With the signing of the Additional Protocol on 23 November 1970, Turkey acquired 210 (of the original 400) million USD loan it sought while agreeing to lower its own customs duties in 12 and 22 year-periods. The same could not be said about the opposition, which represented EU/rope as a potential hindrance against Turkey's economic development. The JP government, in turn, while accepting the relevance of the opposition's portrayal of membership to EEC as carrying risks for the economy (B2b), nevertheless cautiously sustained its own representation of EU/rope as bolstering Turkey's economic development and contributing to Turkey's political security. As such, JP (1965-1971) remained ambivalent on economic grounds while sustaining its confidence in the diplomatic and political significance of what it achieved in the negotiations.

\section{Turkey Suspends Its Obligations vis-à-vis the Customs Union (1978)}

The 1970s brought change and transformation to the EEC, and political and economic upheaval to Turkey. EEC's transformation comprised of four key moves: the trade agreements with the Group of 77 (a group of developing states organized within the United Nations to promote their common economic interests in 1970); the adoption of the Global Mediterranean Policy (whereby the Community agreed to some level of trade facilitation in agricultural products with North Africa, 1972); accepting Greece in 1976 as a full member of the EEC (and later Portugal and Spain, respectively in 1978 and 1979); and the decision to phase out the guest workers' scheme in EC Member States (1974). These developments gave rise to insecurities about political isolation and economic marginalization of Turkey vis-à-vis EU/rope. These insecurities were further aggravated under conditions of turbulence in domestic political and economic situation. The foreign exchange crisis impeded gas and oil imports and caused shortages in many other essentials. The violent strife between left and right wing groups further destabilized the country. Between the 12 March 1971 memorandum issued by the Military and the 12 September 1980 coup d etat, eleven governments came into and out of office. Four of these were short-lived coalitions, and two were caretaker governments set up to carry the country through the general elections.

Our analysis of Turkey's policy-makers during this turbulent era revealed two representations of EU/rope to be prevalent: EU/rope as a source of the risk of diplomatic isolation vis-à-vis the International Society (B1b) and EU/rope as a hindrance against Turkey's economic development (B2b). The former representation came to prevail at a time characterised by anxiety stemming from the advancement of Greece's status vis-à-vis the EEC. Especially in the aftermath of the 1974 Cyprus Peace Operation, Turkey's policy-makers exhibited uneasiness with the progress Greece was making on the membership track. Turkey's foreign policy during this period was dominated by the Cyprus conflict and the encounter with USA over the issue of opium production and the arms embargo. As the EEC welcomed Greece, Turkey's policy-makers repeatedly voiced their anxiety stemming from what they considered to be a preferential attitude toward Greece (Dışişleri Bakanlığı, 1976).

The second representation that prevailed at the time was EU/rope as a hindrance against Turkey's economic development (B2b). For example, in 1974, Foreign Minister Turan Güneş (RPP) told the Press that the government would 'take all necessary measures to prevent the EEC from exploiting Turkey' ("AET'nin Bizi Sömürmemesi için Tedbir Alacağız," 1974). Two years later in 1976, the Foreign Minister Çağlayangil (JP), when leaving the EEC 
Council of Ministers meeting at Brussels, told the Press that 'Turkey could suspend the Agreement. It is possible to live without the EEC. Turkey can live without EEC but in the West' (Birand, 1976, p. 1). The prevalence of the latter representation had its roots not only in Turkey's inability to fulfil its duties but also the EEC's transformation, which, in turn, meant a change in Turkey's status vis-à-vis the Community. Having agreed to lower trade barriers for EEC products, Turkey was now faced with the risk of losing its 'privileged' position vis-à-vis the EEC - the very privilege it thought it had secured through the Ankara Agreement. Now that the EEC had extended such privileges to others, Turkey's policy-makers no longer so felt so privileged. Finally, the EEC's decision to phase out the guest workers' scheme meant that Turkey faced the risk of a decrease in workers' remittances and, as a result, an important source of income. The next RPP government formed under the Premiership of Bülent Ecevit, the new head of the RPP, asked for 8 billion USD loan as well as trade concessions from the EEC (Birand, 1978, p. 6). Following the EEC's refusal, and during the preparations for the Fourth Five Year Plan, Turkey decided to suspend its obligations vis-à-vis the customs union.

The late 1970s, then, proved to be a critical turning point in Turkey's policy-makers' discourses on EU/rope. While both political parties' policy-makers had previously represented the EEC as a booster of Turkey's economic development by virtue of the credits it could provide, when the EEC proved unforthcoming in extending loans, their representation shifted to that of EU/rope as a hindrance against Turkey's economic development (B2b). Against the background of Turkey's policy-makers' long-standing anxiety regarding Greece's advanced status vis-à-vis EU/rope, representations of EEC/EU as a source of the risk of diplomatic isolation also became prevalent during this period (B1b).

\section{Turkey Applies to Join the European Community (EC) for Full Membership (1987)}

The 12 September 1980 coup brought Turkey-EEC relations to a halt. While the EEC did not take an explicit stance, the Council of Europe rejected the credentials of delegations from Turkey, which actively prevented them from taking their seats in the Assembly (Karaca, 2010, pp. 161-184). In the meantime, the EC was preoccupied with two major issues. First, they integrated the relatively less-developed economies of Greece, Portugal and Spain into the Common Market. Second, they gave a start to the process of converting the Common Market into a single market whereby all barriers against freedom of movement of capital, services, people, and goods would be abolished. The Single European Act, which defined the roadmap for the creation of the economic union in Europe, was signed in 1986 and came into effect in July 1987.

1987 was also the year Turkey decided to apply for full membership to EC. Following the return to multi-party democracy in 1983, Turgut Özal's Anavatan Partisi (Motherland Party, MP) had come into office. The first MP government (1983-1987) applied for full membership right before the general elections of November 1987. As with the 1959 decision to apply for EC membership, Greece again factored in the equation. Premier Özal announced the application decision to the Motherland Party's Group in the Parliament by highlighting how the membership of Greece to EC constituted leverage against Turkey. Accordingly, Özal represented EU/rope as a source of anxiety by virtue of constituting a source of the risk of Turkey's diplomatic isolation vis-à-vis the International Society (B1b). Yet he also pointed to EEC membership as the solution to the very problems it caused (B1a), thereby exhibiting ambivalence characteristic of previous administrations.

During this period the European Parliament passed various resolutions on Turkey's domestic and international problems (including 'The Decision in relation to the Political Solution for the Armenian Problem' in 1987, 'The Situation in Cyprus' in 1988, and 'The Situation of Kurds in Turkey' in 1992). These resolutions were met by Turkey's policy-makers' representations of EU/rope as a source of the risk of diplomatic isolation vis-à-vis the International Society. During the discussions in the National Assembly about the decision on the Armenian problem, Foreign Minister Vahit Halefoğlu said 'the Turkish nation has never bowed under foreign pressures...Turkey's application to be a member of the EC will not be affected by such partial, bigoted and unbalanced decisions' (Çayhan, 1997, p. 308). The resolution passed by the Grand National Assembly represented the European Parliament as a tool in the hands of those who scheme against 'Turkey's territorial unity' (Çayhan, 1997, p. 313 and 315).

What was new during the MP period was that Turkey's policy-makers began to move away from previous governments' stress on civilizational commonality with EU/rope as insurance against the risk of diplomatic isolation. Instead they portrayed EU/rope as a community of values accepting of Turkey (B3a) and located the grounds of such acceptance in common political values (but not culture or civilization). Consider Foreign Minister Halefoğlu's words spoken at a general discussion on EU/rope at the Grand National Assembly:

Turkey's membership to the EEC is a natural requisite of the Republic's policy of joining the Western civilization...We will join the European Community while protecting our national 
and cultural values. Therefore Turkey will enrich Europe's political and cultural life. The most important shared characteristic of Turkey and Europe is our embrace of pluralistic democracy and human rights as an indispensable aspect of our style of life (Çayhan, 1997, p. 294).

A short-lived MP government set up by Mesut Yilmaz (June 1991-November 1991) broadened the list of commonalities in its program: pluralist democracy, free elections and market economy (Karluk, 2003, p. 702). This shift in discourse was significant in two ways. By way of defining EU/rope as a community of values, and defining those values in political terms, Turkey's policy-makers exhibited an awareness of the transformation that EU/rope has gone through since 1959. At the same time, by way of seeking to locate that common ground in political values alone, MP policy-makers were defining Turkey outside of EU/ropean civilization in a way no previous administration had done. Through identifying a source of commonality other than joint membership to Western civilization (as previously emphasised by successive RPP and JP governments) successive MP governments exhibited ambivalence toward EU/rope on political grounds: The MP government portrayed EU/rope both as a source of the risk of diplomatic isolation vis-à-vis the International Society (B1b) and a community of values accepting of Turkey (B3a).

\section{The Customs Union Agreement (1995)}

The Motherland Party lost the 1991 elections. The centre-right Doğru Yol Partisi (True Path Party, TPP) and the centre-left Sosyal Demokrat Halkçı Parti (Social Democratic People Party, SDPP) formed a coalition government led by Süleyman Demirel, Head of TPP (1991-1993) and later by Tansu Çiller (1993-1995). It was Çiller who signed the Customs Union Agreement in 1995.

During this period, conspicuously scarce were representations of EU/rope as bolstering or hindering Turkey's economic development. The government pointed to 'free trade' but no other dimension of the Customs Union and made little of its potential implications for the economy. Çiller's coalition partner, Head of SDPP and Foreign Minister Murat Karayalçın, in his address to the Grand National Assembly, highlighted how 'the development policies of our country are based on free trade. That is why we are in search for ways to export our products more efficiently to the Community: that will be achieved through the Customs Union' (Çayhan, 1997, p. 436). Çiller, in a public address, said there would be more trade with the EU because of the Customs Union, and continued, 'Turkey should not pay the price of exclusion in the world which has been parcelled by regional trade blocs' ("Çiller'den Haydi Türkiyem," 1995). Considering the challenge joining the Customs Union constituted for a Turkey already suffering from a trade deficit and $150 \%$ inflation rate per annum, and against the background of concerns raised during the 1970s about the potential negative impact of EEC accession on the economy, the government's lack of reference to economic in/security is revealing in terms of the centrality of the political in/securities and solutions in Turkey's relations with EU/rope (Note 13).

At the moment of the signing of the Customs Union, then, the representation that prevailed was EU/rope as a source of the risk of diplomatic isolation vis-à-vis the International Society (B1b) and as a community of (political) values that can be accepting of Turkey (B3a). As with previous MP governments, the TPP-SDPP coalition government too wrote Turkey out of EU/ropean civilization but sought common ground in the commonality in political values.

\section{EU Rejects Turkey's Candidacy; Turkey Suspends Political Dialogue with the EU (1997)}

The December 1997 Luxembourg European Council meeting resulted one of the most serious crises in Turkey's relations with EU/rope. In the Presidency Conclusions, the Council affirmed Turkey's candidacy while voicing serious criticisms regarding foreign and domestic political matters (European Council, 1997). At the time, a coalition government made up of Demokratik Sol Parti (Democratic Leftist Party, DLP) of Ecevit and Yilmaz's MP was in office. They responded by withdrawing of PM Y1lmaz's attendance to the Conference of Europe, which was planned to bring together the Member States and the candidates. Even more stern was the decision to suspend political dialogue with the EU. Premier Yılmaz, speaking to the New York Times, explicitly represented EU/rope as a source of the risk of diplomatic isolation vis-à-vis the International Society (B1b) and as a community of values that is rejective toward Turkey (B3b). He went on to establish a link between the two as follows:

So we come to the conclusion that even if we meet all the conditions being put to us, the real argument against our membership will still be there. The most important decision in Luxembourg, I believe, is the construction of a new Berlin wall, a cultural Berlin wall (Kinzer, 1997). 
Asked to clarify what he meant by the Berlin Wall analogy, PM Y1lmaz replied: 'Religious discrimination, of course' (Kinzer, 1997).

While identifying EU/rope as a source of the risk of diplomatic isolation vis-à-vis the International Society, the government went on the assault to counter representations of Turkey not belonging to EU/rope conceived as a civilizational project (Note 14). Foreign Minister Ismail Cem was the most active proponent of those policy-makers who highlighted the duality of Turkey's culture including elements from both 'Western' and 'Eastern' cultures (B3a). The point being, both partners to the MP-DLP coalition government used the same representations in responding to the 1997 decision of the EU: EU/rope as a source of the risk of diplomatic isolation vis-à-vis the International Society (B1b) and EU/rope as a community of values that is rejective toward Turkey (B3b). Different from previous MP and TPP-SDPP governments, Foreign Minister Cem expressed ambivalence in a different way. He did not write Turkey out of EU/ropean civilization by seeking the common ground in political values alone. Rather Cem sought to bring Turkey and EU/rope together on a civilizational common ground by pointing to centuries of history of enmeshment of civilizations (B3a). Different from RPP or JP governments of previous eras, Cem accepted the plurality of civilizations but also highlighted centuries of give and take between 'East' and 'West', which practically made them indistinguishable in Anatolia, he maintained.

\section{EU Recognizes Turkey as a Candidate Country (1999)}

The crisis in Turkey-EU relations came to an end at the 1999 Helsinki European Council, where Member States confirmed that 'Turkey is a candidate State destined to join to the Union' (EuropeanCouncil, 1999). The government at the time was a fragile coalition set up by Ecevit's DLP, MP and Milliyetçi Hareket Partisi (Nationalist People's Party, NPP) (1999-2002).

Even as Turkey-EU relations exhibited an all time high, ambivalence continued to characterise Turkey's policy-makers' representations of EU/rope. To Cem, the Helsinki decision was significant not only for Turkey's future but also in terms of what was EU/rope to be. In an article simultaneously published in several European dailies, he wrote:

The EU is now deciding on its enlargement process. One important decision is what role to offer Turkey, which provides Western E.U.rope's main historical, cultural and economic links to Eastern horizons. The choice that the EU makes will either provide the EU with a crucial bridge of conciliation with civilizations with other characteristics, or will be discriminatory and have no effect, or even negative effects on the persisting dichotomies (Cem, 2000, p. 138).

As such, FM Cem sustained above-mentioned representations of EU/rope as a community of values accepting of Turkey (B3a) and EU/rope as a source of/solution to the risk of diplomatic isolation vis-à-vis the International Society (B1a/B1b). This indicates that non-military and non-specific insecurity of policy-makers in relation to acceptance of Greece to and exclusion of Turkey from EU/rope was still present in 1999. The latter was particularly visible when Cem alluded to Greece in his speech: 'If the borders of Europe end with Greece, this can create problems for Turkish-Greek relations', he said ("Cem Uyardi," 1999).

\section{EU Decides to Begin Accession Negotiations with Turkey (2004)}

At the 2004 Brussels European Council, Member States agreed that 'on the basis of a report and recommendation from the Commission that Turkey fulfils the Copenhagen political criteria, the European Union will open accession negotiations without delay' (European Council, 2004). Between 1999 and 2004 both Turkey and the European Union had undergone significant changes. For the EU, the source of change was the run up to and the achievement of the 2004 enlargement. For Turkey, it was the 2002 elections and the coming to power of the Adalet ve Kalkınma Partisi (Justice and Development Party, JDP) - a party set up by politicians who formerly belonged to the Milli Görüss (National Outlook) tradition of Turkey's Islamist right - a tradition that never before had come to office as a single party government.

In the run up to 2004, JDP policy-makers oscillated between representations of EU/rope as a booster of/hindrance against Turkey's development (B2a/B2b) and EU/rope as a source of/solution to the risk of diplomatic isolation vis-à-vis the International Society $(\mathrm{B} 1 \mathrm{a} / \mathrm{B} 1 \mathrm{~b})$. Both the political and economic insecurities were visible in the following statement by PM Recep Tayyip Erdoğan:

When enlargement is completed, the European Union will be the biggest economic and political bloc, which extends from the Atlantic Ocean to Russia and the Ukraine in the East and to Turkey in the Balkans, with a population of 600 million, complete with its integration on many levels, and achieved the customs union, single market, monetary and economic 
union and finally a political union. We should ourselves the question: would it serve our interests to stay outside of this gigantic bloc? Are we going to wait and watch as many candidate counties, which are lagging behind Turkey in different areas, get ahead of Turkey through the benefits of membership, as in happened in the case of Greece? (Erdoğan, 2003).

In this statement, Erdoğan represented EU/rope as a source of the risk of diplomatic isolation vis-à-vis the International Society. The example of Greece came up once again, and in a way similar to previous times - as contributing to the risk EU/rope constitutes in terms of Turkey's diplomatic isolation.

The issue of the economy was raised within the context of giving reassuring messages to the government's detractors at home and abroad. Foreign Minister Abdullah Gül highlighted the benefits both sides were to accrue from a favourable decision:

The opening of negotiations with Turkey next year can only further improve the stability and international standing of our economy. As the EU is our major trade partner and foreign investor, full integration will further encourage the Turkish and European economies to merge. Turkish economy, with its dynamism and capacity will be an asset for Europe. Never a burden. Turkey is not after all taking a share from the European 'cake'. Turkey herself will make this cake bigger. Our recent economic reforms and the recent performance of the Turkish economy is a proof of this dynamism and capacity (Gül, 2007, p. 278).

Yet at the same time JDP policy-makers sought to de-emphasise the economic dimension:

We surely would like to obtain the additional benefits of the EU to our economy. However, this is not the main dynamic, the main reason that drove us toward membership. Our main objective is to benefit from the combined development experience of the continent of Europe, and to enrich the colours of Europe by adding our own colour to them (Erdoğan, 2004a).

As regards EU/rope as a community of values, just before the Brussels European Council, on 14 December 2004, PM Erdoğan (2004b) addressed JDP's Parliamentary group meeting and made the point that it befell on EU/rope to prove that EU/rope is not rejecting of Turkey on cultural grounds (B3a/B3b). Foreign Minister Gül concurred:

Turkey's EU membership will mean that Europe has achieved such maturity that it can incorporate a major Muslim country into its fold. And that EU stands for common values and institutions rather than common religion. For Turkey, EU membership will mean anchoring more than a century old western vocation into the highest standards of democratisation, good governance and integration. For the world, this would evidence that civilizations line up in terms of their democratic vocation, and not on the basis of religion' (Gül, 2007, p. 29).

To recapitulate, the discourses of JDP policy-makers were structured around all three binaries. In particular, JDP policy makers oscillated between representing EU/rope as a source of and as a solution to the risk of diplomatic isolation vis-à-vis the International Society $(\mathrm{B} 1 \mathrm{a} / \mathrm{b})$ and EU/rope as a community of values accepting/rejective of Turkey (B3a/b). In JDP policy-makers' discourses, the risk of diplomatic isolation was represented as stemming from EU/rope being a community of values rejective of Turkey on cultural grounds. Rather than seeking to find a common civilizational ground (as Cem did in a previous era), JDP policy-makers' discourses wrote Turkey out of EU/ropean civilization and sought commonality in the practice of dialogue of civilizations. In doing so, dialogue was also portrayed as one of the values EU/rope and Turkey shared among other political values. The point being, JDP governments picked up Cem's civilizational rhetoric but with a significant difference. While Cem had sought to highlight how little sense it made to talk about EU/rope and Turkey as separate civilizations as if they did not have a shared history, the JDP adopted MP's practice of writing Turkey out of EU/ropean civilization. Instead, they portrayed Turkey as an interlocutor of the Islamic civilization.

\section{Conclusion}

This article analyzed Turkey's policy-makers' understandings of EU/rope at nine critical moments in Turkey-EU relations from 1959 to 2004. Through focusing on policy-makers' discourses we showed the persistence of ambivalence throughout the ups and downs of the relationship. Our analysis showed how their bearing toward EU/rope has been one of inspiration and anxiety all the same. In doing so, we have argued (contra the literature on Turkey-EU relations) that Turkey's stance vis-à-vis EU/rope does not revolve around a single dichotomy (Turkey being European/not). Rather Turkey's policy-makers' discourses are structured around three binaries that are not in a dichotomous relationship. Turkey's policy-makers have employed one, two or all three of these binaries throughout the history of the relationship. Hence the broader argument we make, tapping the insights of 
Post-colonial Studies, that the notion of ambivalence best describes Turkey's policy-makers' stance vis-à-vis Europe.

The table below traces the trajectory of Turkey's policy-makers' discourses on EU/rope as a source of inspiration and anxiety 1959 through 2004.

Table 1. Three binaries in Turkey's policy-makers' discourses on Europe

\begin{tabular}{|c|c|c|c|c|c|c|}
\hline & \multicolumn{2}{|c|}{ B1 } & \multicolumn{2}{|c|}{ B2 } & \multicolumn{2}{|c|}{ B3 } \\
\hline & $\mathrm{a}$ & $\mathrm{b}$ & $\mathrm{a}$ & $\mathrm{b}$ & $\mathrm{a}$ & $\mathrm{b}$ \\
\hline 1959 & & $\mathrm{X}$ & $\mathrm{X}$ & & & \\
\hline 1963 & $X$ & $X$ & & & & \\
\hline 1970 & $X$ & & $X$ & $X$ & & \\
\hline 1978 & & $X$ & & $X$ & & \\
\hline 1987 & $X$ & $X$ & & & $X$ & \\
\hline 1995 & & $X$ & & & $X$ & \\
\hline 1997 & & $X$ & & & $\mathrm{X}$ & $X$ \\
\hline 1999 & $X$ & $X$ & & & $\mathrm{X}$ & \\
\hline 2004 & $X$ & $X$ & $X$ & $X$ & $X$ & $X$ \\
\hline
\end{tabular}

Our analysis of Turkey's policy-makers' discourses since 2004 reveal the persistence of ambivalence notwithstanding the beginning of accession negotiations. Since 2005, 17 out of 33 chapters have been negotiated. This hesitant progress in negotiations has been followed by policy-makers' frequent representations EU/rope 'Christian Club' excluding Turkey on cultural grounds. JDP policy-makers' understanding of EU/rope have continued to reflect EU/rope as a community of values rejective of Turkey based on religion, but accepting of Turkey based on political values and economic benefit.

Although it is problematic to trace linkages between policy-makers' representations of EU/rope and public opinion, there clearly is a downward trend in public support for the EU since 2005 when JDP policy-makers began to frequently employ representations of EU/rope as a 'Christian Club', which aggravated insecurities as expressed by Turkey's policy-makers (B1b and B3b). The following table illustrates the trends since 2001 when Eurobarometer opinion polls first included Turkey.

Table 2. Eurobarometer surveys on public opinion in Turkey about the EU

\begin{tabular}{|c|c|c|c|c|c|c|}
\hline Year & $\begin{array}{l}\text { Tendency to } \\
\text { Trust in EU } \\
\text { institutions }\end{array}$ & $\begin{array}{l}\text { Membership } \\
\text { to the EU }\end{array}$ & $\begin{array}{c}\text { The Image of } \\
\text { the EU } \\
\text { (positive) }\end{array}$ & $\begin{array}{c}\text { Top fear } \\
\text { about the EU } \\
\text { accession }\end{array}$ & $\begin{array}{l}\text { Top three } \\
\text { feelings the } \\
\text { EU creates }\end{array}$ & $\begin{array}{c}\text { What the EU } \\
\text { positively } \\
\text { means }\end{array}$ \\
\hline 2001 & $\begin{array}{c}34 \% \text { (tend to } \\
\text { trust) } \\
66 \% \text { (tend not to } \\
\text { trust) }\end{array}$ & $\begin{array}{c}59 \% \text { (for) } \\
14 \% \text { (against) } \\
12 \% \text { (neither) }\end{array}$ & $51 \%$ & $\begin{array}{c}\text { End of } \\
\text { national } \\
\text { currency } \\
(54 \%)\end{array}$ & N/A & $\begin{array}{c}\text { Economy } \\
(45 \%)\end{array}$ \\
\hline 2003 & $\begin{array}{l}49 \% \text { (tend to } \\
\text { trust) } \\
51 \% \text { (tend not to } \\
\text { trust) }\end{array}$ & $\begin{array}{c}67 \% \text { (for) } \\
11 \% \text { (against) } \\
14 \% \text { (neither) }\end{array}$ & $51 \%$ & $\begin{array}{c}\text { Abandoning } \\
\text { language } \\
(51 \%)\end{array}$ & N/A & N/A \\
\hline 2004 & $\begin{array}{l}51 \% \text { (tend to } \\
\text { trust) } \\
49 \% \text { (tend not to } \\
\text { trust) }\end{array}$ & $\begin{array}{c}62 \% \text { (for) } \\
12 \% \text { (against) } \\
20 \% \text { (neither) }\end{array}$ & $63 \%$ & $\begin{array}{c}\text { Abandoning } \\
\text { language } \\
(59 \%)\end{array}$ & $\begin{array}{c}\text { Hope }(45 \%) \\
\text { Trust }(30 \%) \\
\text { Anxiety } \\
(17 \%)\end{array}$ & $\begin{array}{c}\text { Economy } \\
(48 \%)\end{array}$ \\
\hline
\end{tabular}




\begin{tabular}{|c|c|c|c|c|c|c|}
\hline 2005 & $\begin{array}{l}41 \% \text { (tend to } \\
\text { trust) } \\
59 \% \text { (tend not to } \\
\text { trust) }\end{array}$ & $\begin{array}{c}59 \% \text { (for) } \\
20 \% \text { (against) } \\
17 \% \text { (neither) }\end{array}$ & $61 \%$ & $\begin{array}{c}\text { Abandoning } \\
\text { language } \\
(62 \%)\end{array}$ & $\begin{array}{c}\text { Hope }(42 \%) \\
\text { Trust }(25 \%) \\
\text { Anxiety } \\
(21 \%)\end{array}$ & $\begin{array}{c}\text { Economy } \\
(43 \%)\end{array}$ \\
\hline 2007 & $\begin{array}{l}25 \% \text { (tend to } \\
\text { trust) } \\
75 \% \text { (tend not to } \\
\text { trust) }\end{array}$ & $\begin{array}{c}52 \% \text { (for) } \\
25 \% \text { (against) } \\
15 \% \text { (neither) }\end{array}$ & $53 \%$ & N/A & N/A & N/A \\
\hline 2009 & $\begin{array}{l}38 \% \text { (tend to } \\
\text { trust) } \\
62 \% \text { (tend not to } \\
\text { trust) }\end{array}$ & $\begin{array}{c}48 \% \text { (for) } \\
26 \% \text { (against) } \\
15 \% \text { (neither) }\end{array}$ & $46 \%$ & N/A & N/A & $\begin{array}{c}\text { Economy } \\
\text { (Note 15) } \\
(33 \%)\end{array}$ \\
\hline
\end{tabular}

N/A: Not available (Note 16)

Sources: The table is prepared based on the Eurobarometer surveys conducted in Turkey since 2001 following the acceptance of Turkey as an official candidate (Note 17).

In conclusion, three observations are in order.

- First, while economic insecurities have played an important role in the discourses of Turkey's policy-makers in the early years of Turkey-EEC/EU relations, over the years they have been trumped by political insecurities. Even during the Customs Union negotiations of the 1990s, the government in office made the case to audiences at home and abroad less in economic and more in political terms. While representations of EU/rope as a booster of/hindrance against Turkey's economic development seems to have made a comeback in the discourses of JDP policy-makers in the 2000s, the latter has insisted that the sources of their inspiration are rooted in EU/rope's political achievements and less so in economic feat. This took place against the background of Turkey's public opinion that seem to find the economy the most meaningful aspect of the EU (see table 2).

- Second, whereas policy-makers until the mid-1980s sought to remedy their anxieties through joining what they considered to be the (Western) civilization (without distinguishing between its cultural and political dimensions) since the mid-1980s, they have increasingly written Turkey out of EU/ropean civilization and sought a political common ground. On the one hand, it is possible to consider this shift in policy-makers' representations of EU/rope (from a community of values accepting of Turkey by virtue of shared civilisation, into a community of values rejective of Turkey in cultural terms but accepting of it in political terms) as a consequence of EU/ropean policy-makers' own vacillations toward Turkey. On the other hand, the shift in policy-makers' discourse from representing Turkey as belonging to Western (RPP and JP), s both Western and Islamic (MP, TPP and SDPP), an enmeshment of the two (DLP), to belonging to and offering oneself as the interlocutor of Islamic civilization (JDP) suggests that, Turkey's policy-makers' increasingly frequent attempts to seek a common ground in political but not cultural values have their roots in domestic politics and not only international relations. Considering the public opinion's observations regarding the European project as 'hope' (see table 2), the public is yet to acknowledge MP and later JDP's search for a common ground in political values.

- Finally, through the JDP era, EU/rope has been represented in Turkey's policy-makers' discourse as a source of the risk of diplomatic isolation vis-à-vis the International Society. This finding is in contrast to those who have argued that security concerns of Turkey have diminished in relation to the EU/rope since JDP coming to power (Dağı, 2001). Non-military and non-specific insecurities continue to prevail in policy-makers' discourses where EU/rope is represented as an 'actor' that has not so benign 'designs' regarding Turkey's unity and territorial integrity.

\section{References}

AET'nin Bizi Sömürmemesi için Tedbir Alacağız. (1974). Milliyet (pp. 1).

Avcı, G. (2004). Turkish Political Parties and the EU Discourse in the Post-Helsinki Period. In M. Uğur, \& N. Canefe (Eds.), Turkey and European Integration: Accession Prospects and Issues (pp. 194-214). London: Routledge. 
Bhabha, H. K. (1984). Of Mimicry and Man: the Ambivalence of Colonial Discourse. October, 28(Spring), 125-133.

Bhabha, H. K. (1994). The Location of Culture. London: Routledge.

Bilgin, P. (2009). Securing Turkey through Western-oriented foreign policy. New Perspectives on Turkey, 40, 105-125.

Birand, M. A. (1976). AET Toplantısı Ertelendi. Milliyet (pp. 1)

Birand, M. A. (1978). Türkiye AET Kaynaklarından 5 Yıl için 8 Milyar Dolar Bekliyor. Milliyet (pp. 6).

Birand, M. A. (2000). Turkey's Quest for Europe 1959-1999. Istanbul: Doğan.

Bora, T., \& Canefe, N. (2002). Intellectual Roots of anti-European sentiments in Turkish Politics: the Case of Nationalist-Conservative Tradition and Radical Turkish Nationalism. Turkish Studies, 4, 121-141.

Bull, H., \& Watson, A. (1985). The Expansion of International Society. Oxford: Clarendon Press.

Buzan, B., \& Diez, T. (1999). The European Union and Turkey. Survival, 41(1), 41-57.

Çağlayangil, İ. S. (1969). Türkiye-AET Ortaklık Anlaşması. Milliyet (pp. 9).

Çalış, Ş. (2001). Turkey-EU Relations: Search for Identity, Political Actors and Change. Ankara: Nobel.

Çayhan, E. (1997). Turkey-EU Relations from the Past to the Present and Political Parties' Considerations. Istanbul: Boyut.

Cem Uyardi. (1999). Radikal (pp. 1).

Cem, İ. (2000). Turkey in the 21st Century. Nicosia: Rustem.

Chronology of Turkey-European Relations (1959-2009). (2009). Retrieved November 5, 2010, from http://www.abgs.gov.tr/index.php?p=112\&l=2

Çiller'den Haydi Türkiyem. (1995). Hürriyet (pp. 9).

Cos, K., \& Bilgin, P. (2009). Stalin's Demands? Constructing the 'Soviet threat' in Turkey's Foreign Policy. Foreign Policy Analysis.

Dağı, İ. (2001). The European Union and Turkey: Whereabouts are we in Westernization?. In İ. D. Dağı, R. Gözen, \& Ş. Çalış (Eds.), Turkey's Foreign Policy Agenda: Identity, Democracy, Security. Ankara: Liberte.

Dışişleri, B. T. C. (1976). Foreign Policy Documents 1975-1976. Ankara: Office of Prime Ministry Public Relations and Information.

Doğan, E. (2005). The Historical and Discoursive Roots of Justice and Development Party's EU Stance. Turkish Studies, 6(3), 421-437.

Erdoğan, R. T. (2003). Başbakan Erdoğan'ın 29 Mayıs 2003 tarihli Meclis Konuşması. Retrieved November 11, 2010, from http://www.soneraksoy.net/tayyiperdogan/mecliscalismalari.htm

Erdoğan, R. T. (2004a). Başbakan Erdoğan'ın 01 Haziran 2004 tarihli Meclis Konuşması. Retrieved November 11, 2010, from http://www.soneraksoy.net/tayyiperdogan/mecliscalismalari.htm

Erdoğan, R. T. (2004b). Başbakan Erdoğan'ın Grup Konuşması. Retrieved November 11, 2010, from http://www.belgenet.com/2004/erdogan_141204.html

European Council. (1999). The Helsinki European CouncilPresidency Conclusions.

European Council. (2004). The Brussels European Council Presidency Conclusions.

European Council. (1997). The Luxembourg European Council Presidency Conclusions.

Gül, A. (2007). Horizons of Turkish Foreign Policy in the New Century. Publications of Ministry of Foreign Affairs.

Gülmez, S. B. (2008). The EU Policy of Republican People's Party: An Inquiry on the Opposition Party and Euro-Skepticism in Turkey. Turkish Studies, 9(3), 423-436.

Günver, S. (1985). The Story of Fatin Rüşı̈̈ Zorlu. Ankara: Bilgi.

Hariciye ve Savunma Vekilleri Paris'e Gitti. (1959). Milliyet (pp. 1).

Heper, M., Öncü, A., \& Kramer, H. (Eds.). (1993). Turkey and the West: Changing Political and Cultural Identities. New York: IB Tauris \& Co Ltd. 
Karaca, K. (2010). Turkish Pioneers of a United Europe. İstanbul: NTV Yayınları.

Karluk, R. (2003). The European Union and Turkey (7th ed.). Istanbul: Beta.

Kinzer, S. (1997). Turkey, Rejected, Will Freeze Ties to European Union. The New York Times. Retrieved November 12, 2010, from http//www.nytimes.com/1997/12/15/world/turkey-rejected-will-freeze-ties-to-eu ropean-union.html

Kösebalaban, H. (2007). The Permanent "Other"? Turkey and the Question of European Identity. Mediterranean Quarterly, 18, 87-111.

Krieger, E. (2006). Turkey's Fragile EU Perspectives since the 1960s. In H. L. Kieser (Ed.), Turkey Beyond Nationalism: Towards Post-Nationalist Identities (pp. 167-174). London: I.B.Tauris.

Kürkçüoğlu, Ö. (1980-1981). An Analysis of Atatürk's Foreign Policy, 1919-1938. Turkish Yearbook of International Relations (Vol. 20, pp. 133-189).

Ling, L. H. M. (2002). Postcolonial international relations: conquest and desire between Asia and the West. Houndmills, Basingstoke, Hampshire; New York: Palgrave.

McLaren, L., \& Müftüler-Baç, M. (2003). Turkish Parliamentarians' Perspectives on Turkey's Relations with the European Union. Turkish Studies, 4(1), 195-218.

McSweeney, B. (1999). Security, Identity and Interests: A Sociology of International Relations. Cambridge University Press.

Müftüler-Baç, M., \& McLaren, L. (2003). Enlargement Preferences and Policy-Making in the European Union: Impacts on Turkey. Journal of European Integration, 25(1), 17-30.

Naff, T. (1984). The Ottoman Empire and the European States System. In H. Bull \& A. Watson (Eds.), The Expansion of International Society (pp. 143-169). Oxford: Clarendon Press.

Öniş, Z. (2003). Domestic Politics, International Norms and Challenges to the State: Turkey-EU Relations in the Post-Helsinki Era. Turkish Studies, 4(1), 9-34.

Ortak Pazar Antlaşması İmzalandı. (1963). Milliyet (pp. 1), 13 September.

Rumelili, B. (2004). Constructing Identity and Relating to Difference: Understanding the EU's Mode of Differentiation. Review of International Studies, 30, 27-47.

Rumford, C. (2002). Failing the EU Test? Turkey's National Programme, EU Candidature and the Complexities of Democratic Reform. Mediterranean Politics, 7(1), 51-68.

Sezer, D. (1974). Turkey's Economic Relations. In M. Gönlübol (Ed.), Turkish Foreign Policy through the Events (3rd ed.). Ankara: Ankara Üniversitesi Siyasi Bilgiler Fakültesi Yayınları.

Sükan, F. (1991). Speeches of Prime Minister Adnan Menderes at the Grand National Assembly. Ankara: Kültür.

Suzuki, S. (2005). Japan's Socialization into Janus-Faced European International Society. European Journal of International Relations, 11(1), 137-164.

Suzuki, S. (2009). Civilization and Empire : China and Japan's Encounter with European International Society. Milton Park, Abingdon, Oxon \& New York: Routledge.

Tanıyıc1, Ş. (2010). Europeanization of Political Elite Discourses in Turkey: A Content Analysis of Parliamentary Debates 1994-2002. Turkish Studies, 11(2), 181-195.

Uğur, M. (2004). Economic Mismanagement and Turkey's Troubled Relations with the EU: Is there a link? In M. Uğur, \& N. Canefe (Eds.), Turkey and European Integration: Accession Prospects and Issues (pp. 75-99). London: Routledge.

Uygun, H. (1969). Ortak Pazar'dan 400 Milyon Dolar İstedik. Milliyet (pp. 11).

Watson, A. (1992). The Evolution of International Society : A Comparative Historical Analysis. London \& New York: Routledge.

Yurdusev, A. N. (2004). The Ottoman Attitude Toward Diplomacy. In A. N. Yurdusev (Ed.), Ottoman Diplomacy: Conventional or Unconventional? (pp. 5-35). Houndmills: Palgrave Macmillan.

Zhang, Y. (1991). China's Entry into International Society: Beyond the Standard of 'Civilization'. Review of International Studies, 17, 3-16.

Zürcher, E. J. (1993). Turkey: A Modern History. London: I. B.Tauris. 


\section{Notes}

Note 1. Exceptions to this statement include McLaren and Müftüler-Baç's(2003) survey of Turkish MPs. This study covers the period of 1999-2002 (the survey itself was conducted in April-May 2000) and focuses specifically on the MPs' views on the European Union(see alsoTaniy1c1, 2010). Avc1's(2004) analysis looks at Turkey's political parties' discourses on the EU in the post-Helsinki era. There are also Bora and Canefe(2002), Gülmez(2008), and Doğan(2005) offering analyses of specific political groups' views on the EU.

Note 2. We use the term 'EU/rope' to highlight how Turkey's policy-makers' discourses refer to Europe and the European Economic Community/Union interchangeably.

Note 3. Republican leaders here refer to the founders of the Republic.

Note 4. Not to forget significant parts of the Empire that came under British and French rule before, during or after WWI.

Note 5. Capitulations were 'granted' by the Sultan in an earlier era when the Ottoman Empire was at the peak of its military power. In time, the power balance shifted between Ottoman Empire and its European counterparts. They were removed with the signing of the Lausanne Treaty.

Note 6. The foregoing draws upon (Bilgin, 2009).

Note 7. For a discussion of 'non-military and non-specific' insecurities within the European context, see (McSweeney, 1999).

Note 8. Japanese and Chinese experiences with the International Society suggest that other responses were possible. See, for example, (Suzuki, 2005; Zhang, 1991).

Note 9. (cited inKürkçüoğlu, 1980-1981, p. 138; also see Zürcher, 1993)

Note 10. (Kürkçüoğlu, 1980-1981, pp. 138-139)

Note 11. See ("Chronology of Turkey-European Relations (1959-2009)," 2009).

Note 12. The primary sources we have analysed include government programs, public addresses and press statements by Presidents, Premiers and Ministers in office. We have collected these primary sources printed collections of official documents about Turkey-EU relations, the website of the Grand National Assembly, and printed collections of policy-makers' speeches. Çayhan (1997) offers a collection of Grand National Assembly debates on Turkey-EEC/EU relations. We have also made use of memoirs and journalistic books of interviews with key actors, especially for earlier periods when policy-makers scarcely communicated with the public on foreign policy. We have also surveyed the centre-right daily Milliyet for press statements. Milliyet is the only newspaper that has made its archive starting from 1950 available online.

Note 13. We extended the scope of our research to verify whether there were indeed so few statements about economic insecurity in this key moment. In addition to Milliyet, we surveyed the dailiesHürriyet, Sabah, Radikal, Cumhuriyet, and YeniYüzyıl.

Note 14. In March 1997, following the European Christian Democrats Summit, Belgian PM stated that he considered the EU as a civilizational project and that Turkey culturally was not a part of it (Birand, 2000, p. 465).

Note 15. The sharp decline in economy as the most positive meaning in Turkey's public opinion can partly be attributed to the recent global economic crisis. Financial problems of some EU Member States (Greece, Ireland, and Portugal) and questions about the future of Euro may have effected public perception in Turkey negatively.

Note 16. In Eurobarometer surveys, some questions are not repeatedly asked in each survey. Not available (N/A) is included to mark the questions that are not asked in the relevant survey.

Note 17. The surveys are: Eurobarometer, Candidate Countries Eurobarometer 2001, Brussels, 2002; Eurobarometer, Public Opinion in the Candidate Countries, Brussels, 2003; Eurobarometer, Public Opinion in the European Union Country Report: Turkey, No: 62, Brussels, 2004; Eurobarometer, Public Opinion in the European Union Country Report: Turkey, No: 63.4, Brussels, 2005; Eurobarometer, Public Opinion in the European Union Country Report: Turkey, No: 68, Brussels, 2007; Eurobarometer, Public Opinion in the European Union Country Report: Turkey, No: 71, Brussels, 2009. 